\title{
Evaluation of the diagnostic accuracy of a hemoglobin $S$ and $C$ screening test: Sickle Scan
}

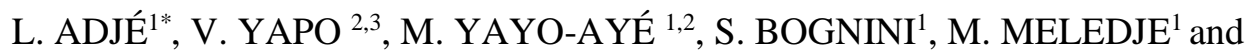 \\ D. SAWADOGO ${ }^{1,2}$
}

\author{
${ }^{1}$ Hematology Unit, Central Laboratory, Yopougon University Hospital, Abidjan, Côte d'Ivoire. \\ ${ }^{2}$ Biological Sciences Laboratory. Department of Pharmaceutical and Biological Sciences, Félix Houphouët- \\ Boigny University of Cocody-Abidjan, Côte d'Ivoire. \\ ${ }^{3}$ Molecular Biology Unit of the CeDReS, Treichville University Hospital, Abidjan, Côte d'Ivoire. \\ *Corresponding author; E-mail: adjemissa@gmail.com; Tel.: +225 07783567 19; 01 BP 2553 Abidjan 01, \\ Côte d'Ivoire.
}

Received: $18-10-2020$

Accepted: 15-02-2021

Published: 28-02-2021

\begin{abstract}
New tools for the rapid diagnosis of hemoglobinosis could encourage the extension of their screening in Africa. Our goal was to assess the analytical performances of a rapid hemoglobin $\mathrm{S}$ and $\mathrm{C}$ detection test, the Sickle Scan. This was a cross-sectional study carried out in March 2019 at the Yopougon Teaching Hospital. The subjects followed for hemoglobinosis as well as the subjects seeking out an electrophoresis of their hemoglobin were included. We carried out the hemogram, the electrophoresis of hemoglobin at alkaline $\mathrm{pH}$ (reference method) coupled with the metabisulfite sickling test (Emmel test) and the rapid detection test to be evaluated. This immunochromatographic test is capable of detecting hemoglobins A, S, and C, and to infer the hemoglobin phenotype from there. The study recruited 191 individuals. The test detected hemoglobins $\mathrm{S}$ and $\mathrm{C}$ with a sensitivity of $99.4 \%$ and $97.7 \%$ respectively; a specificity of $93.3 \%$ and $99.3 \%$. The positive likelihood ratio for hemoglobins $\mathrm{S}$ and $\mathrm{C}$ was 15 and 144 respectively. The negative likelihood ratio was 0.01 for hemoglobin $\mathrm{S}$, and 0.02 for hemoglobin $\mathrm{C}$. The intrinsic characteristics obtained make this test an interesting screening tool for hemoglobinosis $\mathrm{S}$ and $\mathrm{C}$.
\end{abstract}

(C) 2021 International Formulae Group. All rights reserved.

Keywords: Diagnostic test, hemoglobinosis, Abidjan, sensitivity, specificity.

\section{INTRODUCTION}

Hemoglobinopathies are a public health issue in large parts of the world such as SubSaharan Africa. Indeed, more than half of the sickle cell patients worldwide live in that region (Piel et al., 2013). Sickle cell anemia is characterized by the presence of hemoglobin (Hb) $\mathrm{S}$ which results from a structural abnormality in the $\mathrm{Hb}$. People with sickle cell syndrome suffer from chronic anemia with acute and chronic complications of the disease (Gueye et al., 2014; Diallo et al., 2018). Subjects with the heterozygous form are called sickle cell trait carriers. They have little to no clinical manifestations. The combination of a $\mathrm{Hb} \mathrm{S}$ with another hemoglobinopathy can lead to major sickle cell syndromes as seen with the combination of $\mathrm{Hb} \mathrm{S}$ and $\mathrm{Hb} \mathrm{C}$ that promotes the dehydration of the red blood cells and the increase in the concentration of $\mathrm{Hb} \mathrm{S}$. 
Quantitative abnormalities stemming from $\mathrm{Hb}$ synthesis deficiencies have been initially described in populations of the Mediterranean Basin. However, $\beta$-thalassemia is also very widespread in West Africa (De Montalembert, 2008). In Côte d'Ivoire, the overall frequency of sickle cell disease is estimated at about $12.5 \%$ ( Piel et al., 2013; N'draman-Donou et al., 2015) while the frequency of $\beta$-thalassemia varies from 2.3 to $11 \%$ depending on the region considered (Tolo-Diebkilé et al., 2012). In developed countries, the standard of care for diagnosis requires three distinct phenotypic tests including at least one electrophoretic technique (Mario et Sala, 2016). In our limited resources settings, the diagnosis uses only one technique. In addition, the diagnosis is not always financially and geographically accessible. In this context, the recent development of rapid detection tests (RDTs) that do not require some advanced equipment nor electricity, could extend the screening of hemoglobinopathy in Africa. The objective of the current study was to assess the analytical performance of the Sickle Scan Hb S and Hb C RDT.

\section{MATERIALS AND METHODS Study design}

A cross-sectional study was carried out in March 2019 at the University Hospital of Yopougon, Côte d'Ivoire.

\section{Population}

All subjects carrying a hemoglobinopathy and followed-up at the University Hospital, were included. On top of them, subjects unaware of their hemoglobin status for whom an $\mathrm{Hb}$ electrophoresis analysis had been requested by their attending physician were also included. Oral consent from the patient or the accompanying parent (for children) was secured. All eligible subjects who had been transfused in the last three months prior to the start of the study were excluded.

\section{Laboratory testing methods}

Whole blood samples were collected by venipuncture into an ethylene diamine tetraacetate (EDTA) anticoagulant tube. For each participant, a hemogram was performed using a multiple parameters automated hematology analyzer, the Abott's Cell-Dyn Rubby System. A $\mathrm{Hb}$ electrophoresis analysis at alkaline $\mathrm{pH}$ coupled with the metabisulfite sickling test (Emmel test) was also carried out, and served as the gold standard for comparison (Assoumanou et al., 2010). And the Sickle Scan RDT (BioMedomics Inc., Durham, NC, United States of America), was independently run following the manufacturer's instructions by two different operators.

\section{The Sickle Scan test}

The Sickle Scan RDT is a qualitative, cassette-based RDT using the principle of the non-competitive sandwich immunochromatography. It takes advantage of immobilized anti-Hb A, S, and C monoclonal antibodies to infer the $\mathrm{Hb}$ phenotype (AA2, AS, AC, SS, SC and CC) of each patient tested. Of note, one critical limit of the test is its inability to detect $\mathrm{Hb} \mathrm{F}$ as highlighted in the Sickle Scan RDT insert sheet.

\section{Statistical analysis}

The analytical precision of the Sickle Scan RDT was assessed in comparison to the Gold Standard of $\mathrm{Hb}$ electrophoresis + Emmel test. The intrinsic features of the Sickle Scan RDT such as its sensitivity, its specificity, its positive likelihood ratio and its negative likelihood ratio were determined (Nendaz et Perrier, 2004; Delacour et al., 2009; Steichen et al., 2013; Djimadoum et al., 2018).

\section{RESULTS}

The study recruited 191 subjects with an average age of 17 years (1 year to 80 years). The sex ratio was 0.66 . The study population was composed of 178 subjects $(93.2 \%)$ that knew their $\mathrm{Hb}$ phenotype and 13 subjects $(6.8 \%)$ that did not know it. The $\mathrm{SSFA}_{2}$ phenotype was mainly found, followed by the $\mathrm{SFA}_{2}$ phenotype (Table 1). The frequency of the various $\mathrm{Hb}$ fractions is shown in Table 2. With regard to the detection of the diverse $\mathrm{Hb}$ fractions, the intrinsic features of the Sickle Scan RDT are reported in Table 3. Table 4 summarized the cross-comparison of the $\mathrm{Hb}$ phenotypes detected by $\mathrm{Hb}$ electrophoresis 
with those detected by the Sickle Scan RDT. As expected, $\mathrm{Hb}$ electrophoresis properly identified the phenotypes of two subjects as CAF and SCAF phenotype whereas the Sickle Scan RDT characterized them as respectively $\mathrm{AC}$ (or CA) and SC (or CS). All the sickle cell trait subjects $(\mathrm{n}=4)$ were properly typed as such by the RDT. However, $87.5 \%$ (21/24) of the $\mathrm{SAFA}_{2}$ subjects were wrongly identified as AS and $8.3 \%(2 / 24)$ as SS by the Sickle Scan RDT. The intrinsic features of the rapid test are summarized in Table 5.

Table 1: Hemoglobin phenotype identified using the reference standard method (Hb electrophoresis analysis at alkaline $\mathrm{pH}$ ).

\begin{tabular}{lcc}
\hline Phenotype & Number of sample (n) & Frequency (\%) \\
\hline SSFA $_{2}$ & 63 & 33.0 \\
\hline SFA $_{2}$ & 46 & 24.1 \\
\hline SC & 39 & 20.4 \\
\hline SAFA 2 & 24 & 12.6 \\
\hline AA2 $_{2}$ & 9 & 4.7 \\
\hline AS & 4 & 2.1 \\
\hline CC & 4 & 2.1 \\
\hline CAF & 1 & 0.5 \\
\hline SCF & 1 & 0.5 \\
\hline Total & 191 & 100.0 \\
\hline
\end{tabular}

Table 2: Hemoglobin variant identified using the reference standard method.

\begin{tabular}{lcc}
\hline Hemoglobin & Number of sample (N=191) & Frequency (\%) \\
\hline S & 177 & 92.67 \\
\hline A & 84 & 43.98 \\
\hline F & 72 & 37.70 \\
\hline C & 45 & 23.56 \\
\hline
\end{tabular}

Tableau 3: Sickle Scan detection analysis by hemoglobin Variant.

\begin{tabular}{|c|c|c|c|}
\hline & \multicolumn{3}{|c|}{ Hemoglobin } \\
\hline & $\mathbf{A}$ & $\mathbf{S}$ & $\mathbf{C}$ \\
\hline Sensibility & $\begin{array}{c}94.6 \% \\
(\mathrm{CI} 95 \% *: 87-100)\end{array}$ & $\begin{array}{c}99.4 \% \\
(\mathrm{CI} 95 \% *: 98-100)\end{array}$ & $\begin{array}{c}97.7 \% \\
\text { (CI 95\%*:93-100) }\end{array}$ \\
\hline Specificity & $\begin{array}{c}99.3 \% \\
\text { (CI 95\%*: } 98-100) \\
\end{array}$ & $\begin{array}{c}93.3 \% \\
\text { (CI 95\%*: } 81-100) \\
\end{array}$ & $\begin{array}{c}99.3 \% \\
\text { (CI 95\%*: } 98-100) \\
\end{array}$ \\
\hline Positive likelihood ratio & 146 & 15 & 144 \\
\hline Negative likelihood ratio & 0.05 & 0.01 & 0.02 \\
\hline
\end{tabular}


Table 4: Matrix between results achieved by the reference method and the Sickle Scan device, to determine the hemoglobin phenotype.

\begin{tabular}{|c|c|c|c|c|c|c|c|c|c|c|c|}
\hline & & \multicolumn{9}{|c|}{ ELECTROPHORESIS } & \multirow[b]{2}{*}{ TOTAL } \\
\hline & & $\mathbf{A A}$ & AS & CAF & $\mathbf{C C}$ & SAFA2 & SC & SCF & SFA2 & SS & \\
\hline \multirow{6}{*}{ 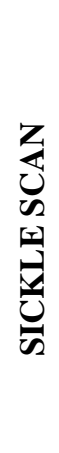 } & $\mathbf{A A}$ & 9 & - & - & - & 1 & - & - & - & - & 10 \\
\hline & $\mathbf{A C}$ & - & - & 1 & - & - & - & - & - & - & 1 \\
\hline & AS & - & 4 & - & - & 21 & - & - & - & - & 25 \\
\hline & $\mathbf{C C}$ & - & - & - & 4 & - & - & - & - & - & 4 \\
\hline & SC & - & - & - & - & - & 38 & 1 & - & - & 39 \\
\hline & SS & - & - & - & - & 2 & 1 & - & 46 & 63 & 112 \\
\hline \multicolumn{2}{|c|}{ TOTAL } & 9 & 4 & 1 & 4 & 24 & 39 & 1 & 46 & 63 & 191 \\
\hline
\end{tabular}

Table 5: Sickle Scan detection analysis by hemoglobin phenotype : $\mathrm{SSFA}_{2} / \mathrm{SFA}_{2}, \mathrm{SC}$ et CC.

\begin{tabular}{ccc}
\hline Phenotype & Sensibility $(\mathbf{C I}: \mathbf{9 5 \%} \%)$ & Specificity (CI : 95\%*) \\
\hline SSFA $_{2} /$ SFA $_{2}$ & $100 \%$ & $96.34(\mathrm{CI} 95 \%: 92-100)$ \\
\hline SC & $97.5(\mathrm{CI} 95 \%: 93-100)$ & $100 \%$ \\
\hline CC & $100 \%$ & $100 \%$ \\
\hline 95\% Confidence Intervals
\end{tabular}

*95\% Confidence Intervals

\section{DISCUSSION}

Overall, the evaluation of the analytical performance of the Sickle Scan RDT focused first on the ability of the test to detect the types of $\mathrm{Hb}$ present in the blood sample of people living in Côte d'Ivoire, Western Africa. We demonstrated that the test showed good sensitivity and specificity $(>93.0 \%)$ regardless of the type of $\mathrm{Hb}$ detected (A, S and C) (Table 3). In addition, the positive likelihood ratios of the RDT for $\mathrm{Hb} \mathrm{S}$ and $\mathrm{C}$ were greater than 10 and the negative likelihood ratios were less than 0.02 . The higher the positive likelihood ratio and the lower the negative likelihood ratio, the greater the diagnostic gain of the test (Delacour et al., 2013; Steichen et al., 2013).

Sickle Scan RDT performances have been studied both in developed countries and in resources-limited countries. In 2016, a study carried out in the United States of America on 139 samples noted a sensitivity and a specificity of respectively $99.5 \%$ and $92.5 \%$ for the detection of the $\mathrm{Hb} \mathrm{S}$ (Mcgann et al., 2016). As for $\mathrm{Hb} \mathrm{C}$, the study found a sensitivity of $100 \%$ and a specificity of $100 \%$. These values are similar to ours (Table 3 ). Based upon the types of $\mathrm{Hb}$ detected with the RDT, we inferred the phenotypes accordind to the manufacturer's guidelines. Thus, for the determination of the $\mathrm{SSFA}_{2} / \mathrm{SFA}_{2}, \mathrm{SC}, \mathrm{CC}$ phenotypes, the sensitivity and specificity of the RDT were good and above $96 \%$ (Table 5). Kanter et al. (2015) reported a sensitivity of $99 \%$ for the detection of the $\mathrm{SSFA}_{2}$ and $\mathrm{SFA}_{2}$ phenotypes, Mc Gann et al. (2016) and Nwegbu et al. (2017) reported $98.4 \%$ and 
$100 \%$ respectively, similar to our finding (Table 5). The specificity of the RDT on our hands for the detection of the $\mathrm{SSFA}_{2}$ and $\mathrm{SFA}_{2}$ phenotypes was lower than the ones reported by these same authors, $99.0 \%, 98.6 \%$ and $98.2 \%$ respectively. Likewise, the "Drepatest" study conducted in West Africa (Segbena et al., 2018) using the same RDT noted in Togo a sensitivity and specificity of $97.6 \%$ and $99.6 \%$ respectively. The sensitivity of the test was 97.5\% (93-100) for the detection of the SC phenotype. Kanter et al. (2015) found 99\%; Mc Gann et al. (2016) and Nwegbu et al. (2017) found a sensitivity of 100\%; Segbena et al. (2018) obtained $97.6 \%$. The specificity of the RDT for that phenotype was $100 \%$ in our study; similar to what Mc Gann et al. (2016) and Segbena et al. (2018) reported.

The 4 subjects carrying the sickle cell trait were correctly detected by the Sickle Scan RDT. However, it should be noted that in 21 other people previously known as $\mathrm{SAFA}_{2}$, the test had displayed "AS" as a phenotype (Table 4). $\mathrm{SFA}_{2}$ and $\mathrm{SAFA}_{2}$ type thalasso-sickle-cell anemia are clinical forms of hemoglobinopathy in sub-Saharan African countries where sicklecell anemia and $\beta$-thalassemia coexist. The Sickle Scan RDT is designed with a lower limit of detection of $\mathrm{Hb} \mathrm{A}$ greater than $25 \%$ which is higher than that of $\mathrm{Hb} \mathrm{S}$ and $\mathrm{C}$ (Kanter et al., 2015). As a result, $\mathrm{SAFA}_{2}$ subjects with a $\mathrm{Hb} \mathrm{A}$ fraction of less than $25 \%$ will be phenotyped as $\mathrm{SSFA}_{2}$ or $\mathrm{SFA}_{2}$. While subjects with sickle cell trait, with their $\mathrm{Hb}$ A fraction greater than $40 \%$ will be correctly classified as AS. Previous studies (Kanter et al., 2015; Mcgann et al., 2016; Nwegbu et al., 2017; Nguyen-Khoa et al., 2018; Segbena et al., 2018) had not assessed the ability of the Rapid Sickle Scan RDT in subjects with the $\mathrm{SAFA}_{2}$ thalassosickle cell form. However, McGann et al. (2016) noted that the distinction between the sickle cell trait and the $\beta+$ Thalassemia associated with sickle cell anemia $\left(\mathrm{SAFA}_{2}\right)$ can prove difficult or even impossible. However, Nguyen et al. (2018) found that $\mathrm{Hb} \mathrm{A}$ and $\mathrm{Hb}$ $\mathrm{S}$ were detectable with the same RDT even when these Hbs were present at less than $1 \%$ and $2 \%$ respectively.
The population of our study was mainly in-patients with known hemoglobinopathy. In fact, $90 \%$ of the subjects recruited were carriers of $\mathrm{Hb} \mathrm{S}$ (Table 1). The aim of this work was to study the intrinsic characteristics of the test, namely the sensitivity, the specificity and the likelihood ratios. The frequency of hemoglobinosis in the study population (Tables 1 and 2), was much higher than the national prevalence of $12.5 \%$ (Piel et al., 2013), but it does not constitute a bias. For the intrinsic characteristics of a screening test do not depend on the frequency of the event studied (Delacour et al., 2013; Steichen et al., 2013). On the other hand, the extrinsic characteristics of the RDT such as the predictive values (positive and negative) that are influenced by prevalence of the event studied could not be evaluated. There is a need of new studies to update the prevalence of hemoglobinopathies in the general population. Those studies will be useful to properly assess both the intrinsic characteristics (sensitivity, specificity, likelihood ratios), and the extrinsic characteristics (positive and negative predictive values) of candidate RDTs. It would also be necessary to assess the ease of use and social acceptability of theses RDTs for the integration of a diagnostic tool into a clinical process requires the evaluation of all those aspects.

\section{Conclusion}

The present study was carried out in Abidjan (Côte d'Ivoire). The results showed some good intrinsic characteristics of the Sickle Scan RDT in identifying Hbs S and C. However, the exact determination of the $\mathrm{Hb}$ phenotypes requires confirmation with the classical diagnostic tests such as $\mathrm{Hb}$ electrophoresis at alkaline $\mathrm{pH}$.

\section{COMPETING INTERESTS}

The authors declare that they have no competing interests.

\section{AUTHORS CONTRIBUTIONS}

$\mathrm{AL}$ carried out the testing using the RDT. AL and MM performed the data mining. $\mathrm{AL}$ and $\mathrm{YV}$ wrote the manuscript. YA carried 
out and interpreted the results of the $\mathrm{Hb}$ electrophoresis test, the Emmel test, and the hemogram. BS monitored the follow-up of the participants to the study. DS conceived, initiated and supervised the entire study.

\section{ACKNOWLEDGEMENTS}

The authors would like to thank all of the patients who agreed to participate in the study.

\section{REFERENCES}

Assoumanou M, Issifou D, Akpona A. 2010. Le test de précipitation en milieu réduit: une alternative au test d'Emmel dans le dépistage de l'hémoglobinose S. Int. J. Biol. Chem. Sci., 4(2): 354-361. DOI:10.4314/ijbcs.v4i2.58123

De Montalembert M. 2008. Syndromes thalassémiques. EMC - Hématologie, (13006-D-17): 1-9. DOI: $10.1016 / \mathrm{s} 1155-$ 1984(08)49950-8

Delacour H, François N, Servonnet A, Gentile A, Roche B. 2009. Les rapports de vraisemblance: un outil de choix pour l'interprétation des tests biologiques. Immuno-Analyse et Biologie Specialisee, 24(2): 92-99.

DOI:10.1016/j.immbio.2009.01.002

Delacour H, Mouline S, Ceppa F. 2013. Mesure des performances et méthode de valorisation des tests biologiques. EMC Biologie Médicale, 8(1): 1-8. DOI: 10.1016/s2211-9698(13)57794-6

Diallo DA, Guindo A, Touré BA, Sarro YS, Sima M, Tessougué O, Baraika MA, Guindo P, Traoré M, Diallo M, Dorie A. 2018. Targeted newborn screening for sickle-cell anemia: Sickling test (Emmel test) boundaries in the prenatal assessment in West African area. Revue d'Epidemiologie et de Sante Publique, 66(3): 181-185. DOI: 10.1016/j.respe.2018.02.007

Djimadoum M, Bessimbaye N, Moussa AM, Tidjani A, Narassem M, Narbe MD, Sangba A, Barro N. 2018. Évaluation de la performance de cinq tests de diagnostic rapide pour le dépistage du virus de l'Immunodéficience Humaine (VIH 1 \&
2) au Tchad. Int. J. Biol. Chem. Sci., 12(5): 2162-2171. DOI: https://dx.doi.org/10.4314/ijbcs.v12i5.18 Gueye PM, Gueye-Tall F, Seck M, Kane MO, Diallo RN, Diatta M, Ndour EM, Doupa D, Faye B, Diop S. 2014. Aggravation de l'anémie et polymorphisme de l'haptoglobine au cours de la drépanocytose au Sénégal. Int. J. Biol. Chem. Sci., 8(3): 975-982. DOI: http://dx.doi.org/10.4314/ijbcs.v8i3.13

Kanter J, Telen MJ, Hoppe C, Roberts CL, Kim JS, Yang X. 2015. Validation of a novel point of care testing device for sickle cell disease. BMC Medicine, 13(1): 225. DOI: 10.1186/s12916-015-0473-6

Mario N, Sala N. 2016. Diagnostic biologique des hémoglobinopathies. Revue Francophone des Laboratoires, (481): 35-47. DOI: $10.1016 / \mathrm{S} 1773-$ 035X(16)30127-7

Mcgann PT, Schaefer BA, Paniagua M, Howard TA, Ware RE. 2016. Characteristics of a rapid, point-of-care lateral flow immunoassay for the diagnosis of sickle cell disease. American Journal of Hematology, 91(2): 205-210. DOI: 10.1002/ajh.24232

N'draman-Donou E, Fofié Y, Adjambri E, Mélèdje MF, Sawadogo D. 2015. Caractérisation et évaluation in vitro de l'effet antifalcimiant des graines de Cajanus cajan (Fabacées) sur les drépanocytes à Abidjan-Côte d'Ivoire. Int. J. Biol. Chem. Sci., 9(5): 2300-2308. DOI:http://dx.doi.org/10.4314/ijbcs.v9i5.4

Nendaz MR, Perrier A. 2004. Sensibilité, spécificité, valeur prédictive positive et valeur prédictive négative d'un test diagnostique. Revue des Maladies Respiratoires, 21(2): 390-393. DOI: 10.1016/s0761-8425(04)71300-5

Nguyen-Khoa T, Mine L, Allaf B, Ribeil J, Remus C, Stanislas A, Gauthereau V, Enouz S, Kim JS, Yang X, Gluckman E, Beaudeux J, Munnich A, Girot R, Cavazzana M. 2018. Sickle SCAN TM (BioMedomics) fulfills analytical conditions for neonatal screening of sickle cell disease. Annales de Biologie 
Clinique, 76(4): 416-420. DOI: 10.1684/abc.2018.1354

Nwegbu MM, Isa HA, Nwankwo BB, Okeke CC, Edet-Offong UJ, Akinola NO, Adekile AD, Aneke JC, Okocha EC, Ulasi T, Abjah U, Ugwu NI, Okolo AA, Madu A, Emodi I, Girei A, Balogun TM, Diaku-Akinwumi IN, Ohiaeri C, Brown BJ, Olaniyi JA, Hassan A, Awwalu S, Okoh DA, Nnodu OE. 2017. Preliminary Evaluation of a Point-of-Care Testing Device (SickleSCAN ${ }^{\mathrm{TM}}$ ) in Screening for Sickle Cell Disease. Hemoglobin, 41(2): 77-82.

DOI:10.1080/03630269.2017.1329151

Piel FB, Patil AP, Howes RE, Nyangiri OA, Gething PW, Dewi M, Temperley WH, Williams TN, Weatherall DJ, Hay SI. 2013. Global epidemiology of Sickle haemoglobin in neonates: A contemporary geostatistical model-based map and population estimates. The
Lancet, 381(9861): 142-151. DOI: 10.1016/S0140-6736(12)61229-X

Segbena AY, Guindo A, Buono R, Kueviakoe I, Diallo DA, Guernec G, Yerima M, Guindo P, Lauressergues E, Mondeilh A, Picot V, Leroy V. 2018. Diagnostic accuracy in field conditions of the sickle SCAN® rapid test for sickle cell disease among children and adults in two West African settings: The DREPATEST study. BMC Hematology, 18(1): 1-10. DOI: $10.1186 / \mathrm{s} 12878-018-0120-5$

Steichen O, Ranque B, Grenier B. 2013. Choisir un test diagnostique. In EMC: Traité de Médecine Akos. Elsevier Masson: Paris; 1-10.

Tolo-Diebkilé A, Kouakou B, Méité N, N'Dhatz-Comoé E, Ayemou R. 2012. Profil épidémiologique, clinique et thérapeutique de la bêta- thalassémie mineure du noir africain. Rev Int Sc Méd, 14(3): 227-231. 